\title{
URBAN CONFLICT AND POPULAR VIOLENCE THE GUILDHALL RIOTS OF 1740 IN NEWCASTLE UPON TYNE*
}

On 26 June 1740 the "very beautiful and sumptuous" Town Court or Guildhall of Newcastle upon Tyne was systematically wrecked by a crowd of angry townspeople, keelmen and local ironworkers, who smashed the woodwork and windows, tore the paintings, and ransacked the archives and treasury. ${ }^{1}$ Contemporary observers were stunned by this unprecedented orgy of destruction, because the campaign of intermittent and fairly orderly protests against the high price of grain which had preceded the 26th had not prepared them for the scale and ferocity of the assault on the corporation's most ostentatious monument to its wealth and authority. The outbreak of popular violence confirmed some people's suspicions that "respectable" grievances served only as a pretext for the mob's brutish desire to loot and plunder: to others it vindicated the traditional argument that it was not only unjust but also unwise "to provoke the necessitous, in times of scarcity, into extremities, that must involve themselves, and all the neighbourhood in ruin". 2

Historians who have considered these disturbances have proffered a variety of explanations bearing a strong resemblance to those adopted by contemporaries: they range from a belief that disorder was an elementary and instinctive reaction to hunger and distress to a suggestion that the participants were "for putting in practice the old levelling principles". 3

* All dates cited refer to the year 1740 , unless otherwise specified.

1 H. Bourne, The History of Newcastle on Tyne (Newcastle, 1736), p. 125; Brief against all the prisoners, 4 August, Tyne and Wear Archives, Newcastle (hereafter TWA), $394 / 56$.

${ }^{2}$ Carr to Burnett, 1 July, Northumberland County Record Office, Newcastle (hereafter NCRO), ZCE 10/13; E. Chandler, A Charge Delivered to the Grand-Jury (Durham, 1740), p. 4.

3 T. S. Ashton and J. Sykes, The Coal Industry of the Eighteenth Century (Manchester, 1929), pp. 118-19, 131; Ridley's Account of the Riots, NCRO, ZRI 27/8, p. 10, quoted but misattributed in E. P. Thompson, "The Moral Economy of the English Crowd in the Eighteenth Century", in: Past \& Present, No 50 (1971), pp. 126-27; there is no in- 
However, as a result of the upsurge of debate initiated by E. P. Thompson's formulation of the "moral economy" of the crowd, it is becoming increasingly clear that any explanation of such popular protests must take into account a complex pattern of economic, social and political pressures that determined why the stimulus of hunger and the apparent currency of moral values legitimating protest led in one community to a "riot" and in the vast majority to stoical acceptance. ${ }^{4}$

The aim of this article is to further the general debate on the nature of popular protest by examining the interplay of accident and aspiration leading to the outbreak of violent disorder in Newcastle in 1740. It is hoped that this well-documented incident, in a town which had no tradition of food-related disturbances, will illuminate the circumstances in which the poor would resort to physical protest.

The crisis in the Newcastle area, like that in many other parts of the country, stemmed from a combination of heavy rain in the summer and autumn of 1739, which damaged crops and hindered the coal trade, and the fearsome winter which followed. Even in the Midlands the mean temperature remained below freezing for months on end; in the North-East the frost came down hard in late December and lasted well into February, stopping all traffic on the Tyne and bringing economic life in the area and along the East coast to a virtual halt. The Newcastle Courant carried reports of unemployment and of shortages of food, coal and even water, only partially offset by the charity of local magnates, who were themselves affected by the sudden cessation of the usual stream of bills on London generated by the coal trade. ${ }^{5}$ Nor did the thaw bring an end to their troubles. Throughout the spring prevailing north-east winds penned colliers in harbour and interrupted the grain trade: the number of ships clearing customs at Sunderland, for example, was reported to be 500 below normal for the time of year. ${ }^{6}$

dependent evidence for this statement, and Ridley had an interest in representing the crowd in the worst possible light, see below, pp. 344, 346.

4 Thompson, loc. cit.; D. E. Williams, "Were 'Hunger' Rioters Really Hungry? Some Demographic Evidence", in: Past \& Present, No 71 (1976), pp. 70-75; J. Walter and K. Wrightson, "Dearth and the Social Order in Early Modern England", ibid., pp. 22-42.

5 Carr's correspondence, April 1739 - June 1740, NCRO, ZCE 10/12; G. Manley, "Mean Temperatures in Central England 1698-1952", in: Quarterly Journal of the Royal Meteorological Society, LXXIX (1953), pp. 254, 256; E. L. Jones, Seasons and Prices. The Role of the Weather in English Agricultural History (London, 1964), pp. 138-39; T. S. Ashton, Economic Fluctuations in England 1700-1800 (Oxford, 1959), p. 19; Newcastle Courant, Nos 768-71, 774 .

${ }^{6}$ Carr to Coutts \& Co., 11 March; Williamson to Bishop of Durham, 24 May, Public Record Office, London (hereafter PRO), SP 36/50/432. 
The great frost and the unfavourable wind pattern had several important implications. In the first place, there would have been unemployment among keelmen and tradesmen, short-working at the pits, and general distress in Newcastle and the region as incomes contracted severely. As a local writer pointed out, "It is observable in this Place when the Coal Trade is brisk, that all other Business is so too; and when it is otherwise [...] that there is a certain Deadness in all Trafick. It is the Money arising from the Coal Trade, that almost entirely Circulates in this great Town and adjacent Country."7 Thus the final reserves of the poor would have been whittled away, leaving them more vulnerable to any rise in food prices. Second, the long frost rotted the seed in the ground and delayed salvage attempts and re-sowing dangerously long, raising the spectre of a second bad harvest in succession and pushing up food prices even after the thaw had reopened markets. Moreover, the quantity of grain reaching local markets was often further restricted by transport difficulties, the telescoping of the farmers' year, and speculative hoarding. In the first six months of 1740 the prices of rye and oats, the staples of life in the Newcastle area, rose by around 100 per cent, rye from $20-22 /-$ to $36-40 /$ - and oats from $8-9 /-$ to $17-20 /-$ a quarter. $^{8}$

Shortages and price fluctuations on this scale may have had a greater impact because they were such rare events in the Newcastle area. The available evidence suggests that the prices of agricultural produce had remained stable since the early seventeenth century, and certainly there was no general rise or fall in the prices of the main arable crops in the first half of the eighteenth century; seasonal fluctuations too were relatively insignificant. This stability becomes all the more remarkable when it is considered that the population of Durham and Northumberland increased by about 50 per cent in the sixty or seventy years before 1740 , and that this increase was accompanied by a marked redistribution of population towards the industrial areas. Newcastle's population seems to have doubled and was probably just under 30,000 in 1740 ; however, this certainly understates the true size of the urban concentration, since it omits both Gateshead and the village suburbs which formed part of the county of Newcastle. The total population of this embryonic conurbation was probably around 40,000, nearly all of them consumers, rather than producers, of food, and therefore needing the services of an efficient and sophisticated market. Moreover, the expansion and concentration of industrial activity which had taken place in and around the valleys of the Tyne and its

7 Bourne, The History of Newcastle, op. cit., p. 158.

8 Carr's correspondence, January-June. 
tributaries had given a new significance to Newcastle's role as the chief marketing centre for provisions for a wide area beyond its own walls. ${ }^{9}$

These developments had fostered and indeed dictated a corresponding expansion in both agricultural output and the trade in foodstuffs. Clearly an enormous quantity of food, especially grain, passed through the town for sale at its many markets and, in normal circumstances, a combination of imports and local production ensured that the area could be represented as "the most plentiful of any in England for all sorts of Corn". ${ }^{10}$ Newcastle lay in a rich and prosperous agricultural area, where farmers received ample encouragement to meet the demand on their doorsteps, so that it would be a mistake to see it as being utterly dependent on imported grain. Oats, for example, although much in demand as fodder for the large colliery-horse population as well as for human consumption, came mostly from neighbouring counties and could even be exported from the region, as were wheat and barley. ${ }^{11}$ The large imports were of barley and rye, which were said to be consumed in such vast quantities that local supplies could not possibly satisfy demand: yet even with these grains Newcastle merchants could often conduct a healthy export or re-export trade, responding to advice from their extensive correspondence networks. ${ }^{12}$ Much locally produced grain never passed through the official Newcastle markets because corn merchants employed dealers in the small Northumberland ports to make advance contracts with farmers, store, and then ship the grain to wherever the price was most favourable. Demand in Newcastle was usually strong enough to ensure that consumers as well as merchants benefited from the sophistication of the grain trade, but in less fortunate areas it was precisely this sort of traffic that could outrage local opinion in times of dearth. ${ }^{13}$

In 1740, moreover, the impact of food shortages on the Newcastle market was heightened by an unfortunate combination of circumstances, among them the outbreak of war with Spain in December 1739, which disrupted foreign trade because of an embargo on exports and the coastal

9 P. W. Brassley, "The Agricultural Economy of Northumberland and Durham in the period 1640-1750" (B.Litt. thesis, University of Oxford, 1974), pp. 16-34; Bishop Chandler's Visitation, 1736, Newcastle City Library, L 253/21245; Bourne, The History of Newcastle, p. 54.

10 Carr to J. Pelletrau \& Sons, 14 March.

11 Brassley, "The Agricultural Economy", op. cit., pp. 47-48; Carr to Messrs Simpson, 25 March.

12 Carr's correspondence, esp. Carr to Messr Parker, 12 February.

13 Ibid., esp. Carr to Haliburton, 7 March; to Cookson, 28 March; to Petrie, 4 January; to Duffus, 21 March. 
trade because of the threat posed by privateers and the press. ${ }^{14}$ It must also be taken into account that employment in the coal industry was probably suffering from the long-term effects of a cartel which had been operating since 1732 , and which was held to have contributed to the keelmen's strike of $1738 .{ }^{15}$ This strike, the latest in a long succession of disputes between the keelmen and their employers on the issue of wages and working conditions, should have reminded the Newcastle authorities that among the consumers aggrieved by the conjuncture which had disrupted the food markets were many who were accustomed to obtaining redress for their grievances by taking direct and often successful action.

The predominance of large units of heavy industry in the local economy meant that the workforce on Tyneside had the character of an embryonic organized proletariat. Although some employers sheltered behind the comfortable fiction that workers in the coal trade were a "poor thoughtless crew", the cohesion, group loyalty and effective organization displayed in the course of innumerable industrial disputes made this somewhat difficult to sustain. ${ }^{16}$ It was an unwise coal-owner who allowed the stock at pithead or staith to run down at the height of the shipping season, for he was then at the mercy of his pit- or waggonmen. ${ }^{17}$ The keelmen's strikes in particular often achieved national importance. They produced articulate petitions not only to local dignitaries but even on occasion to the Privy Council; sometimes action was concerted with their counterparts on the Wear, and they usually required both a favourable settlement and considerable armed force to persuade them to return to work. ${ }^{18}$ In 1738 some of them were prepared to uphold their rights against their employers in fairly extreme terms, complaining of "a Barbarity abhored by Jewes, Turks, and Infidals", and demanding that masters as well as men should enter into a yearly bond specifying conditions of service. When some fainthearts demurred at this, their leader replied: "What need you be afraid of [using] Such Expressions to the Magistrates [. . .] When the like have been delivered to the King and Parliament."19

14 Ashton, Economic Fluctuations, op. cit., p. 146; Carr's correspondence, 16 and 21 March, 6 April.

15 Petitions \&c, May 1738, TWA, 394/9.

16 Liddell to Ellison, 14 January 1729, Gateshead Public Library, A $32 / 21$; id. to Cotesworth, 21 November 1710 , ibid., A 25/9.

17 Bowes Papers, ff. 156, 179, John Regenstein Library Manuscripts, University of Chicago.

18 J. M. Fewster, "The Keelmen of Tyneside in the Eighteenth Century", in: Durham University Journal, L (1957-58), pp. 24-33, 66-75, $111-23$.

19 Petitions \&c., May 1738. 
However, although the local industrial workforce could hardly be described as subservient, the magistrates' complaint that they were "too ready, on any Occasion, to join in an Insurrection" was born of panic and prejudice rather than experience. ${ }^{20}$ The frequent "mutinies" in the coal trade were characterized by large, potentially dangerous but disciplined demonstrations rather than by the outbreak of violent disorder. Far from rising in resistance to established authority, the keelmen were concerned to enlist the support of that authority in defence of their customary terms of employment. They usually succeeded, because it was recognized that the social order could not be sustained by repression alone; it was also necessary "to curb and punish those, that by avaritious and illegal practices, grieve and irritate [the common people] into unruliness". Popular violence and disorder were thus kept at bay by a combination of ameliorative and repressive measures, and only erupted when those in authority failed to take appropriate action, as they did in Newcastle in $1740 .{ }^{21}$

The appropriate action in cases of dearth was well-known - it was vital to prevent corn merchants offending public susceptibilities by moving and particularly exporting grain when supplies were barely enough for the home market. It was unfortunate that, since conditions during the winter of 1739-40 had been even worse in Scotland and on the Continent than in England, international grain prices encouraged exports despite dearth at home. Such exports were prevented until May by the embargo on all foreign trade, but exports began from many English ports as soon as it was lifted, despite widespread condemnation of the trade. Newcastle merchants were as eager to take advantage of the situation as those in other ports: in June, Ralph Carr was shipping wheat and oats up to Scotland from his stocks in Newcastle and Northumberland even though Newcastle itself had been opened for the import of foreign oats and later rye because of rocketing prices in the local markets. ${ }^{22}$ Moreover, it is possible that the corporation was known to be sympathetic to exporting merchants. Nearly all the other town authorities who reported riots to the government at this time listed the protestors' grievances with approval and appealed for a ban on exports. Newcastle was a notable exception, perhaps because

${ }^{20}$ Mayor to Duke of Newcastle, 19 July, TWA, 394/11.

21 Chandler, A Charge, op. cit., pp. 10-11; Walter and Wrightson, "Dearth and the Social Order", loc. cit., p. 41 . The government's reaction to the 1719 strike is typical, see PRO, SP 44/281/60, 62-3, 66-7.

22 Ashton, Economic Fluctuations, p. 46; Newcastle Courant, Nos 786-88; Carr's correspondence, June. 
of the powerful influence of corn dealers within the ruling Merchants' Company. ${ }^{23}$

Repression without offering some measure of conciliation, however, was almost certainly beyond the Newcastle magistrates' reach. The raw and undisciplined town guard was no match for the tough and determined pitand keelmen, and violent confrontations had always been studiously avoided. ${ }^{24}$ The problem was compounded when, as in the case of food riots, popular disturbances were the expression of widespread suffering supported by public sympathy. The correspondence of the sheriff of Durham in connection with the outbreak in Stockton in 1740 shows that very few of the authorities, let alone the rank and file of the posse, had much enthusiasm for putting down this particular type of disorder: most of the justices failed to obey his summons and those ordinary members who did attend were said to share the demonstrators' hostility to grain exports. ${ }^{25}$ It is significant that the Bishop of Durham in his charge to the Grand Jury later in the year took as his text, as Thompson did: "They that withold Corn the People will Curse." 26 This sort of sympathy made it difficult for the authorities to adopt the only sure solution to sustained or extensive popular disturbances, the stationing of a considerable body of regular troops in the area. Using troops to put down civil disorder was both necessary and effective, but it was bitterly opposed by a large and influential section of the nation. This opposition, combined with the fact that the Riot Act had confused the legal position, meant that the civil and military authorities had to tread a very delicate path when using force to restore order: the Porteous case in 1736 was an uncomfortable reminder of their vulnerability. ${ }^{27}$ The Durham justices prepared for their descent on Stockton by declaring their abhorrence of shedding blood and trying to persuade the sheriff that it was his duty to accept full responsibility. He can hardly be blamed for approaching the task with trepidation, haunted by the spectre of the unfortunate Porteous. ${ }^{28}$ The Newcastle authorities also had it in

${ }^{23}$ See for example PRO, SP 36/50/432, 454. Both the Mayor, Cuthbert Fenwick, and his brother Nicholas, one of Newcastle's MPs, were boothmen (corn merchants). On the other hand, the customary efficiency of the local market may have blunted the magistrates' reactions to dearth.

24 From N. Ridley, 23 June 1710, PRO, SP 34/12/101.

25 From Williamson, 10 June, PRO, SP 36/51/28; D. G. Isaac, "A Study of Popular Disturbances in Britain 1714-54" (Ph.D. thesis, University of Edinburgh, 1953), pp. 286-92.

${ }^{26}$ Chandler, A Charge, p. 6; Thompson, "The Moral Economy", p. 76.

27 Tony Hayter, The Army and the Crowd in Mid-Georgian England (London, 1978), chs 1-3. Captain Porteous was convicted for murder and lynched after the Edinburgh city guard under his command had fired on an unruly crowd.

28 Williamson to Bishop of Durham, 10 and 15 June, PRO, SP 36/51/28, 92. 
mind - one of them later reported that the rioters there were surprised to see the troops preparing to fire, "which they before imagined could not be done, since the affair of Capt. Porteous at Edinburgh". ${ }^{29}$

Moreover, in 1740 the ordinary problems of law and order were complicated by the approach of an election in 1741, which made the authorities wary of calling in troops or indeed of using any force at all for fear of offending potential voters. ${ }^{30}$ In Newcastle there was a long history of bitter political strife, encouraged by competition for the support of a large and independent electorate - nearly 2,400 freemen were to vote in 1741 and they included a number of obviously humble men, like colliers, carriagemen and bricklayers. ${ }^{31}$ The candidates, however, like the corporation, were members of the town's elite, which was drawn almost exclusively from two of the three sections of the Merchants' Company and which tended to be both closed and hereditary. Its members were usually united by marriage but not necessarily by anything else, except in defence of the corporation's numerous and very lucrative privileges against the attacks mounted by both disgruntled freemen and hostile country families. It was natural for some freemen to resent the magnates, whose power, embodied in the corporation and the Merchants' Company, had reduced them to second-class citizens in their own town. It was also natural for the country families, many of which had risen through Newcastle's trade and maintained houses and power bases in the town, to resent the control which the corporation exercised over the river traffic, the potentially lucrative riverbanks, and the even more lucrative wayleave rights through the town's extensive property. They had fought a long and ultimately unsuccessful campaign after 1718 to prevent the town purchasing the Walker estate, claiming that the magnates would exploit it for their own benefit and not that of the freemen..$^{32}$ Richard Ridley, who dominated the corporation for many years before his death in 1739 , was accused of doing precisely this in an election poem directed against his son's candidature in 1741.

He had our Way-leaves, - we but little Rent:

And on the Ruin of us all did mount. ${ }^{33}$

Town politics were this intimately entangled with the infinitely more vicious quarrels and feuds which split both town and country magnates

29 Ridley's Account. The Porteous case was also mentioned in connection with the Bristol riots in 1740, see Hayter, The Army and the Crowd, op. cit., pp. 31-32.

30 Williamson to Bishop of Durham, 24 May.

${ }^{31}$ Poll at the election of Members to serve in Parliament, 1741, NCRO, ZAN M 17/38.

32 J. Ellis, "The Taming of the River Dragon: Newcastle upon Tyne in the Eighteenth Century", in: Cardiff Studies in Local History, forthcoming.

33 E. Chicken, No. This is the Truth (1741?), p. 5. 
over the spoils of the coal trade. Wayleave, land and mineral rights were all fertile sources of dispute, and competition was so fierce that it could be literally cut-throat. There were not many instances in this generation of the violence, extending to sabotage and assault, which had marked the last, but resentments simmered on, above all against the Ridleys, whose great influence in both the town and the coal trade had antagonized many sections of the community. Richard Ridley was posthumously condemned as

Revengeful, bitter, ready to oppress;

The City's Torment, and the Poor's Distress.

He had possibly tried to have a rival poisoned in 1725 , and it is noticeable that when his son, Matthew, stood for Parliament in 1741, the victim's family and adherents threw away a vote rather than give it to a Ridley. ${ }^{34}$ Moreover, Matthew Ridley created further difficulties for himself by pulling out of an agreement with the Grand Allies, the partnership which controlled a considerable share of the Tyne's coal trade..$^{35}$ These disputes and local rivalries seem to have played a crucial part in the outbreak of violence in Newcastle in 1740, transforming a strictly limited popular protest against conditions in the corn markets into a bitter, physical attack on the corporate splendours of the Guildhall.

The first signs of trouble in Newcastle coincided with the lifting of the embargo and the outbreak of rioting in many other parts of the country on or around 19 May. In Stockton these disturbances were on an impressive scale and successfully prevented the loading of wheat for export for an entire month, despite the pleas of the Durham justices and the arrival of some troops. ${ }^{36}$ In Newcastle, however, the demonstrations were insignificant: a small group of women, incited by a leader calling herself "General" or Jane Bogey, ringing bells and impeding the passage of horses carrying grain through the town. Five of them were committed but discharged at Newcastle sessions a few days later, and the situation seems to have remained quiet thereafter. It was certainly thought safe to withdraw a regiment of dragoons stationed in the town in the last week of May, a move which meant that the nearest body of regular troops was at Berwick. ${ }^{37} \mathrm{~A}$ few weeks later it was no longer possible to be complacent. Disturbances ${ }^{34}$ Ibid., p. 4; J. Ellis, "The Poisoning of William Cotesworth, 1725", in: History Today XXVIII (1978), pp. 752-57; Poll at the election, 1741.

${ }_{35}$ Ridley to Dobson, 30 November 1739 , NCRO, ZRI 35/12, Vol. 1.

${ }^{36} \mathrm{PRO}, \mathrm{SP} 36 / 50$ and 51 . Trouble was also reported in Colchester, Peterborough, Kettering, Pembroke, Rhuddlan, Flint and Holywell, always in connection with the movement of grain. See Isaac, "Popular Disturbances", op. cit., p. 9.

${ }^{37}$ Minutes of proceedings at sessions, 21 May, TWA, 394/11; Sessions riot, ibid., 13, p. 1; Newcastle Courant, no 788. 
were breaking out in other North-Eastern towns with such alacrity that the sheriff reported "the Spiritt of rebellion is spread over the Country", and on 17 June orders were sent for three companies of troops to march from Berwick to suppress the troubles south of the Tyne. ${ }^{38}$

The Newcastle magistrates must have been expecting trouble to spread north, and one of them indeed blamed "some turbulent Spirits among those of the Collieries upon the River Wear" for inciting the disturbances that eventually broke out in the town. ${ }^{39}$ Actually the attack came from the north rather than the south, and the most "foreign" of the participants came from no further afield than Gateshead. In the early hours of the morning of 19 June, as the night shift was going on at the Bank pit of Heaton colliery, they decided to strike over a dispute about their coal allowance, which may have been whittled away as an economy measure. ${ }^{40}$ It seems, therefore, that the initial response of the workforce to distress was a characteristic appeal to industrial action. However, by $3 \mathrm{a} . \mathrm{m}$. the grounds of the protest had shifted from a labour dispute to a more "traditional" type of grievance: the men began to stop other pits, apparently by threatening to cut the winding gear, and a march on Newcastle was organized to protest about the price and export of grain. ${ }^{41}$

Between 60 and 100 pitmen eventually arrived on the Sandhill, the main market place, at about 5 a.m., only to discover that this was scarcely the best time to stage a public demonstration. They therefore dispersed to gather support, and by 10 a.m. there were 300 or 400 people on the Sandhill, equipped with the drum, horn and flying colours that were the conventional trappings of the pre-industrial crowd. When the magistrates failed in an attempt to capture the horn, they realized that negotiation was the only course open to them, so they admitted a deputation bearing a list of the demonstrators' demands to the Guildhall. Meanwhile crowds were roaming the streets, seizing corn from inns, horses and carts, and piling it on the Sandhill under guard, with the threat that it would be appropriated if their demands were not met. Few raids were made on granaries at this stage, although in one case a group of women and children forced an entry with the aid of some Heaton pitmen. ${ }^{42}$ In general the demonstrators

38 PRO, SP 36/51/92 and 154.

39 Ridley's Account, p. 1.

40 The coal allowance had been one of the keelmen's main grievances in 1738, Petitions \&c., May 1738. It is perhaps significant that one local coal-owner described the Grand Allies' employees as "starved", The Correspondence of Sir James Clavering, ed. by H. T. Dickinson [Surtees Society Publications, CLXXVIII] (Gateshead, 1967), p. 213.

41 Carr to Coutts \& Co., 22 June.

42 Subsequent investigations of these disturbances confirmed the prominent part played by pitmen, but seem to have understated the role of women and children, see below, pp. 346-47. 
behaved in an orderly and disciplined fashion, conforming to the pattern of "model", semi-carnival confrontations characteristic of similar foodrelated disturbances, and they were rewarded by the successful conclusion of their negotiations with the magistrates and corn merchants. The latter agreed to reduce their prices at the next market: wheat would be sold at $4 /-$ a bushel ( 24 per cent below the current price), rye at $3 /-(37$ per cent), oats at $1 / 6 \mathrm{~d}$ ( 40 per cent), and massingham ${ }^{43}$ at $3 / 6 \mathrm{~d}$. The demonstrators then deposited the confiscated corn in the public weigh-house and dispersed for the night. ${ }^{44}$

However, when they re-assembled in even greater numbers the next morning, the situation deteriorated. Although the merchants later protested that they were willing to abide by their agreement, it seems that too many shops and stalls remained closed, and by $10 \mathrm{a} . \mathrm{m}$. the pitmen and their allies were seizing loaves of bread in the market. They subsequently launched a wholesale assault on the granaries, with women and children once again playing a prominent part; however, even the official sources admit that the demonstrators were often persuaded to leave empty-handed. Their spokesmen were by now demanding that wheat should be sold at $3 / 6 \mathrm{~d}$ a bushel, rye at $2 / 6 \mathrm{~d}$, oats at $1 / 3 \mathrm{~d}$ and massingham at $3 /-$, and they extended their price-fixing to white peas, oatmeal, cheese, butter, beans and barley. Moreover, this escalation of the dispute was accompanied by a return to the aims and methods of industrial action. There were calls for a rise in wages and, as more collieries closed and the coal trade ground to a halt, the crowd in Newcastle was expanding at an alarming rate. The frightened magistrates estimated that they already had about 1,000 demonstrators on their hands and they awaited the inevitable influx of keelmen with understandable trepidation. Abandoning conciliation, they sent off a request for military aid, called up the town guard, and appealed to the coal-owners to summon their employees to help restore order. ${ }^{45}$

Matthew Ridley certainly obeyed this summons, appearing outside the walls early on the 21 st with 60 horsemen and over 300 on foot, all of them bearing oak cudgels and wearing green boughs in their hats for identification. Backed by this private army, the sheriff read the proclamation, arrested some of the ringleaders, and dispersed the crowds sufficiently to

43 Massingham or maslin was a mixed grain, often consisting of wheat and rye.

44 From the Mayor, 20 June, PRO, SP 36/51/127; TWA, 394/10 (subscription by 7 pitmen), 12 (proclamation, 20 June, and confessions), 51 (informations), 52 (examinations); Brief against all the prisoners; evidence of N. Fenwick, TWA, 394/56.

45 From the Mayor, 20 June; TWA, 394/12 (examinations and confessions), 15 (publication of corn prices, 20-24 June), 51 (informations), 52 (examinations); Brief against all the prisoners; brief against Trotter, TWA, 394/56; evidence of Fenwick. 
enable the guard to take possession of the gates. While they remained on duty they enforced an uneasy calm, isolating the disgruntled consumers within the town from their allies in the suburbs. ${ }^{46}$ However, the authorities' victory was by no means assured and there remained several sources of apprehension. First, the forces of law and order had been depleted by the refusal of the Grand Allies to co-operate and call up their employees, perhaps because this would involve attacking their own Heaton men, but more probably because they would not work with the town authorities in general and Matthew Ridley in particular. ${ }^{47}$ Second, the disruption of trade in Newcastle kept farmers away from the markets so that little corn was on sale, while the town was flooded with country people anxious to take advantage of the low prices agreed on the 19th. The magistrates reacted by restricting sales of corn to regular customers and to those townspeople or coal workers who could produce certificates to that effect. This rationing may have been behind unrest at Crowley's metal works out at Swallwell, where the workers were narrowly dissuaded from following the example of the Heaton pitmen. ${ }^{48}$

It was in any case an inadequate response to the grievances of even the approved customers inside the town. It was known that some merchants retained hoards of grain, which they were reluctant to sell at a loss - selling small quantities of oatmeal cheaply, as the Merchants' Company did on the 25 th, was more likely to confirm the existence of these stocks rather than to appease public opinion. Moreover, Newcastle merchants reacted to the disturbances by hastily diverting to Amsterdam shipments coming in from the Baltic, preferring to risk the consequences of an acute shortage of bread in local markets to facing the certainty of a commercial loss. ${ }^{49}$ The magistrates were powerless to prevent this, but they could have done something to remove or palliate one dangerous and obvious source of discontent. A ship loaded with foreign rye had actually docked at the Keyside before it could be diverted to another port and it remained there, untouched, a natural focus for rumour and discontent. ${ }^{50}$

In these circumstances, it was imperative that the authorities should remain vigilant and maintain the guard on the gates. Yet on the afternoon of the 25 th, when the magistrates met to renew the guard's authorization, the Mayor not only refused to sign the order, but also retired to his house at

46 TWA, 394/12 (confessions), 51 (informations); Brief against all the prisoners; evidence of Fenwick; Ridley's Account, pp. 2-4.

47 The Correspondence of Sir James Clavering, op. cit., p. 213.

48 TWA, 394/12 (advertisement, 24 June), 52 (examinations).

49 Ridley's Account, pp. 5-6; minutes of rioters' proceedings, TWA, 394/11; Carr to Messrs Frigg \& Gordon and to Trotman, 24 June.

50 Ridley's Account, p. 7. 
Elswick, leaving the town to its fate. One account of this incident blames a quarrel with the corn merchants for Fenwick's defection, but other sources are adamant that it was in fact a matter of "parliamentary party". The Mayor was the younger brother of a sitting Tory MP, whose seat Matthew Ridley, the heir to a considerable political interest in the town, the governor of the Merchants' Company and the saviour of law and order on the 21 st, was to contest in the 1741 election as a Whig. Perhaps the Fenwicks resented the extent to which he had taken control of the situation and sought to curtail his opportunities to make political capital out of it. ${ }^{51}$

This conflict of interest within the corporation and the paralysis of authority that was its result bears much of the responsibility for the destruction of the Guildhall. During the early hours of the morning of the 26th keelmen coming up-river from Shields began to stop traffic on the Tyne, and by 6 a.m. a great crowd was assembled on the Sandhill. Meanwhile six or seven keelmen had been dispatched up to the Crowley works to bring the metal workers to join the demonstration. The protestors demanded that the shipment of rye be distributed and the magistrates were ready to agree, thinking that this would divert the crowd's attention while the guard was reformed and armed. To accomplish this a group of 20 or 30 armed freemen, led by Ridley, began about midday to force their way down to the Keyside through an estimated 3,000 hostile demonstrators. They were jostled, a scuffle broke out, and then some of the "White Stocking Gentlemen" fired into the crowd, killing at least one man and wounding others.

After this provocation all hell was let loose: the freemen were assaulted, their muskets were seized and they were pursued up the steps of the Guildhall by a volley of stones, closely followed by a wave of infuriated humanity intent on smashing anything that stood in their way. By the time that the 100 or so of "Crowley's Crew" arrived at 3 or 4 p.m., having met the news of the shootings on their way through Gateshead, the sack of the Guildhall and its official records was well under way, and it was still in full swing when three companies of troops arrived from Morpeth at about 8 in the evening. They succeeded in dispersing the crowds and restored order, but the magistrates did not feel really secure until the whole regiment marched in from Berwick. ${ }^{52}$ Their Colonel reported a month later that "the people have hardly recovered their fright, so that at present there is nothing

51 Minutes of rioters' proceedings; Ridley's Account, p. 6; Carr to Coutts \& Co., 1 July, and to Yelloly, 5 July; J. Sykes, Local Records; or, Historical Register of Remarkable Events (Newcastle, 1866), I, p. 166, quoting manuscript notes by Ald. Hornsby.

52 From the Mayor, 27 June, PRO, SP 36/51/198; minutes, 1 July, ibid., 229; Ridley's Account, pp. 6-9; TWA, 394/10 (examinations), 51 (informations), 52 (examinations); minutes of the rioters' proceedings; Brief against all the prisoners; evidence of Fenwick. 
they are so fond of as the Buffs" - in view of more usual reactions to the army, this continued popularity among the substantial citizens is evidence of the seriousness of the outbreak on the 26th. ${ }^{.3}$

It seems clear that the poorer Newcastle consumers had during the winter of 1739-40 suffered from a degree of distress unprecedented within popular memory, and were therefore all the more incensed when merchants not only juggled with the market, thus maintaining prices, but also threatened to export what little corn remained in the area before the new crop, which was in any case reported to be both late and deficient, came onto the market. The magistrates' response to this unrest was weakened by the normal defects of civil authority, the lack of military presence, the extent of popular sympathy for the demonstrators, and the indecision generated by the Porteous case. Moreover, the approaching election not only made potential candidates more cautious, but it also re-vivified the power struggle within the town and made each faction anxious to deny its rivals a share of the limelight. This was an explosive mixture, and the outbreak of violence which ensued undoubtedly horrified "respectable" citizens who were thus unpleasantly reminded that "the beginnings of popular commotions are, like the letting out of Waters, small in the beginning [. . .]; but suffered to grow to a flood, carry all before them". ${ }^{54}$ Nevertheless, except for the one moment of panic which led to the fatal shootings, the conduct of both demonstrators and magistrates was remarkably restrained.

The prosperous townspeople maintained that it was only the hours that it took to break into the Guildhall strongroom and remove upwards of $£ 1,300$ from it, thus allowing the army to march to the rescue, that saved Newcastle from a night of fire and looting - in effect the "old levelling principles" alleged in Ridley's own account of the incident. However, as a general statement this has as little validity as have similar claims that the shootings served as a mere pretext for the violent and destructive instincts of the "mob" ${ }^{55}$ Many threats were uttered in the heat of the moment and indeed a certain hostility towards magistrates and freemen was only to be expected in the circumstances; there is a vivid description of a woman going down on her knees in front of the terrified magistrates and crying:

${ }^{53}$ The Manuscripts of the Earl of Carlisle, preserved at Castle Howard [C. 8551] (London, 1897), p. 195.

54 Chandler, A Charge, pp. 10-11.

55 Ridley's Account, pp. 10-11; Carr's correspondence, 1 and 5 July; The Manuscripts of the Earl of Carlisle, op. cit., p. 195. At least one observer believed that the crowd would have remained orderly had it not been for the killings: NCRO, ZSW 212/8. 
"Blood for blood." 56 Yet the crowd's vengeance was to a large extent vented on inanimate objects. The captured weapons were smashed and thrown in the river rather than being used on the magistrates, all of whom escaped from the Guildhall unscathed, being escorted to their homes in a kind of mock triumph. Moreover, the only private property which seems to have been seriously threatened was Ridley's house at Heaton, a natural target in view of its owner's part in the shootings - he was certainly frightened enough to brick all his papers and valuables away in a vault just in case. Both he and his property, however, survived the onslaught of popular resentment untouched. In fact the only penalty which Ridley paid for his part in the events of the 26th was the gift of a magnificent weapon to his political rivals, who were able to blame the town's sufferings on his pride, which

Destroys its Honour by a sham Pretence,

Of heading Fops to stand in its Defence;

Pulls down its Grandeur for a private End. ${ }^{57}$

The authorities themselves exercised restraint when they turned their attention to identifying and punishing those who had taken part in the disturbances. They collected the names of 91 people in connection with the initial demonstrations between the 19th and the $21 \mathrm{st}$, and their investigations confirmed the prominence of pitmen, and particularly Heaton pitmen, among the crowd. Twenty of the indictments which were eventually brought before the Assizes were directed against pitmen, showing the authorities' concentration on those identified as the instigators of the unrest rather than on the main body of "rioters", many of whom were said to be women and children. Moreover, punishment was meted out with a lenient hand. Two-thirds of those whose names appear in the official records escaped prosecution entirely, and in most other cases the authorities proceeded no further than a successful indictment. There were only two actual convictions for felony, both with sentences of seven years transportation, and one conviction of riot, with a sentence of six months imprisonment and a further twelve months on securities. Thus the official response to this initial phase of essentially peaceful popular protest was both moderate and selective.

${ }^{56}$ Evidence of Fenwick.

57 Ridley to Dobson, 6 July; Chicken, No, op. cit., pp. 3-4, 8. Ridley, who stood a fair chance of being identified as the local Porteous, was protected by his colleagues. None of the accounts of the events of the 26th sent to London or used at the trials mentions the shootings, and Ridley's name was omitted from the final versions of indictments listing those magistrates present in the Guildhall at the time of the attack. From the Mayor, 27 June; Draft and copies of indictments, 4 August, TWA $394 / 53$ and 56. 
Table 1. Occupations of those reported to have taken part in disturbances in Newcastle, June 1740

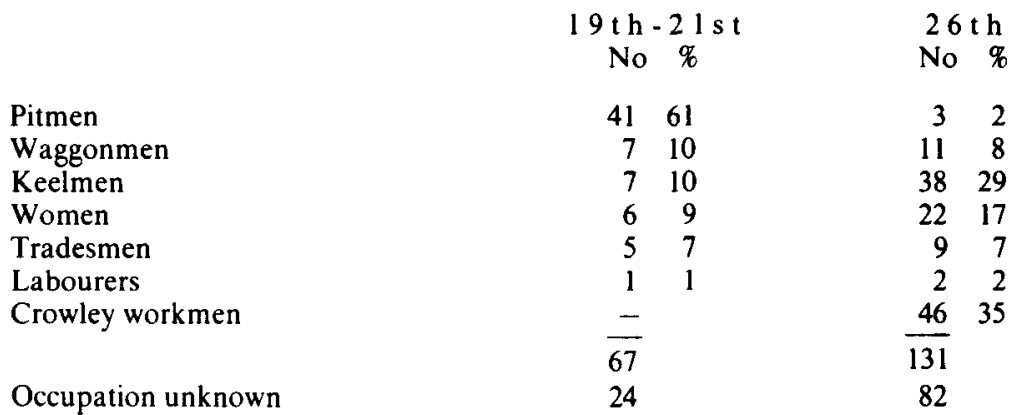

Source: TWA, 394/10-13, 51-53, 56.

Table 2. Action taken against the demonstrators

\begin{tabular}{lcccc} 
& $19 \mathrm{th}-21 \mathrm{~s} \mathrm{t}$ & \multicolumn{2}{c}{$26 \mathrm{th}$} \\
& No $\%$ & No $\%$ \\
$\begin{array}{l}\text { No legal proceedings } \\
\text { Some proceedings but no }\end{array}$ & 30 & 33 & 57 & 27 \\
prosecution & 35 & 38 & 44 & 21 \\
Indicted & $\frac{26}{91}$ & $\frac{112}{213}$ & 53
\end{tabular}

Source: ibid.

The larger and more serious outbreak on the 26th produced a far more vigorous reaction. Not only were 213 people identified in the course of the investigations, but a very high proportion of them were indicted on charges of riot, assault or felony ${ }^{58}$ Moreover, many more in dictments were taken to trial. 15 of the 70 riot and assault indictments found at the 1740 Assizes were tried in 1741 , and 19 of the 40 successful felony indictments were tried immediately. On the other hand, the punishments awarded were relatively lenient. There were several acquittals, and even the five men convicted of felony escaped with sentences of seven years transportation. It should be noted that a thief who stole 20 pairs of woollen stockings from a shop just before the demonstrations was actually sentenced to death at the same ${ }^{58}$ See Tables I and 2. "Crowley's Crew" are probably overrepresented in the official records thanks to their willingness to supply the investigators with the names of colleagues. 
Assizes. The contrast could expose a more sympathetic attitude to this type of popular protest, however felonious, but it could also reflect the authorities' realistic assessment of the power of organized labour on Tyneside. The fact that most of the local collieries had gone on strike while awaiting the verdicts may well have influenced the sentences imposed. ${ }^{59}$ As in all such cases, the authorities had to tread a careful path between enforcing respect for the law and restoring some measure of social harmony to the area in which they themselves had to live out the rest of their lives.

This very practical consideration influenced the response of both local and national authorities to the disturbances of 1740: they recognized the justice of many of the demonstrators' grievances and responded by remedying their previous and disastrous neglect through action to prevent the movement of grain. ${ }^{60}$ On the very day that the Guildhall was wrecked the Lords Justices in London issued an Order in Council to ban exports and enforce the traditional statutes curbing the activities of corn merchants. The order seems to have been enforced and indeed its scope was extended by the Newcastle authorities to cover coastal traffic in grain as well as exports; this aroused furious protests from local merchants, who questioned the legal basis of such an order and argued that "without a New Act of Parliament no person need regard it". However, even the most intransigent merchants had to acknowledge the facts of the situation, and prudence dictated that they should bow to the combined legal and popular pressure by selling their wares in the local markets while the period of dearth lasted. ${ }^{61}$

The disturbances in Newcastle in 1740, like those elsewhere in the country, thus served to re-assert the traditional consensus on the proper measures to be taken in times of dearth, a consensus which had perhaps been weakened by the years of plenty known by the last generation. In the face of a dangerously slow official reaction to corn exports, the initial response of the Newcastle consumers was a remarkably orderly appeal to the local authorities to fulfil their conventional obligations; and the eventual outbreak of violence was the product not of the authorities' failure to meet that appeal, but of exceptional and accidental circumstances. In all this, and despite the prevalence of more "modern" forms of popular protest on Tyneside, the so-called Guildhall riots conform closely to the patterns which have emerged from the study of food-related

59 To Secretary at War, 19 July, TWA, 394/11; Carr to Burnett, 8 August; Newcastle Courant, No 799.

60 See above, pp. 337-38:

61 Order in Council, 26 June, PRO, SP 36/51/183; Carr's correspondence, July-August. 
disturbances in earlier centuries. The aftermath too indicates an important element of continuity, reinforcing the conclusion that "Riots when they did occur were invariably successful in stimulating authoritative action to alleviate grievances." 62

62 Walter and Wrightson, "Dearth and Social Order", p. 41. See also Thompson, "The Moral Economy", p. 126. 